\title{
Evaluation of pharmaceutical education in the State of Libya: An academic perspective
}

\author{
Mohamd M. Milad, Amal Y. Benkorah \\ Department of Pharmaceutics and Pharmacy Practice, Faculty of Pharmacy, University Of Tripoli, Tripoli, Libya
}

\author{
Keywords \\ FIP framework \\ Indicator \\ Libya \\ Pharmacy Education \\ Quality \\ Correspondence \\ Amal Y. Benkorah, PhD \\ Department of Pharmaceutics \\ Faculty of Pharmacy \\ University of Tripoli (UOT) \\ Tripoli \\ Libya \\ a.benkorah@uot.edu.ly
}

\begin{abstract}
Objective: This study evaluates the quality of educational standards in the colleges of pharmacy in the State of Libya using FIP-QA framework which is made of five sections representing the five pillars of quality, namely: context, structure, process, outcomes and impact. Method: A questionnaire was constructed based on the indicators in each section of the framework. Answers were collected by distributing the questionnaire to eight colleges of pharmacy at public universities. Results: 42 out of 50 professors completed the questionnaire. Most participants believe that the context, structure and process of pharmaceutical education in Libya require significant improvement in order to comply with international standards. Conclusions: Since the impact of pharmacy education depends on the previous pillars, it is clear that the current curricula are inefficacious in producing graduates who have the competencies to exercise patient-centred roles, and to address the limitations in providing pharmaceutical care-related services.
\end{abstract}

\section{Introduction}

Many developing countries, including the state of Libya, have faced challenges in the field of pharmaceutical education due to the lack of development in the pharmacy profession. The role of pharmacists has expanded, in the health sector, with increasing needs for contemporary pharmacist services and the expansion of responsibilities of the pharmacist to a further consultative, patient-focused role. This has increased the demand for specialised pharmacists, and emphasised the need for their educational development (Kheir et al., 2008) Therefore, many colleges in developing countries have reformed their pharmaceutical education systems, specifically curricula and training environment (Kheir et al., 2008).

The foundation stone for pharmaceutical education in Libya, a North African Arab country, was the establishment of the first national faculty of pharmacy in 1975 at the
University of Tripoli (UOT) (Faculty of pharmacy - the University of Tripoli, n.d.). Until the mid-nineties of the twentieth century, this faculty stood alone as the only educational institution to provide the Libyan society with competent pharmacists, and then was followed by the establishment of the second faculty of pharmacy at the University of Benghazi (UOB), in the eastern part of Libya in 1989 (Faculty Of Pharmacy - University of Benghazi, n.d.). There are currently a total of seven established faculties of pharmacy in Libya (Global Knowledge Exchange Network, 2009). Bachelor of Pharmaceutical Sciences (B.Pharm.Sc.) is the main offered professional degree which qualifies the graduate to be licensed as a pharmacist. High school diploma scores (of $85.0 \%$ and over) are the only criteria used for admission into a pharmacy college. All government-funded faculties of pharmacy have five year-long programmes. Faculties of pharmacy in both UOT and UOB offer higher academic 
degrees, namely a Master's degree in Pharmaceutical/ Biomedical sciences.

The faculty of pharmacy at UOT, being one of the major government-supported institutions and the leader of pharmacy education in Libya, adopted the British curriculum in its beginnings. The direction of pharmaceutical education globally has been shifting towards being patient centred and outcome-oriented. These changes in practice have led some of the national elite faculty members at UOT, who have experience in the development of educational programmes, to take the responsibility for developing the curricula at their institution to be patient-centred. This has allowed UOT to keep pace with the development that has occurred in both pharmacy education and practice (1st meeting for the Development Committee of the Faculty of Pharmacy, UOT with all sectors of the Libyan pharmaceutical community. Series of 6 meetings (April - December 2015)). However, formal accreditation for these more recent curriculum changes has not yet been established for several reasons, the most important of which are:

i.lack of consensus on the vision and mission of pharmacy education

ii.disagreement on the basic tasks and general visions for the pharmacy profession

iii.failure to update national laws and legislations to keep up with the tasks assigned to pharmacists

Despite the few attempts to develop and improve the quality of pharmacy education in major Libyan pharmacy colleges, such as UOT and UOB, it is still oriented towards pharmaceutical products by focusing on pharmaceutical manufacturing and related sciences rather than on the patient. This contradicts the reality of the country's pharmaceutical situation, which lacks a pharmaceutical industry and has a lack of experts in medical fields to provide an integrated service to the patient and the community. Because of the shift in the profession of pharmacy towards the provision of integrated services, current pharmacists in Libya must work to support patients to reach their desired health outcomes and support the Libyan community at large. Therefore, this role requires that Libyan pharmacists acquire the necessary skills and competencies which are obtained through well designed scientific methods and clinical evidence-based education.

It is, however, worth mentioning that Libyan pharmacy education has witnessed a transformative experience by the introduction of the pharmacy programme of the Libyan International Medical University (LIMU). The programme was established in 2007, as the first private medical university in the country, with the mission of developing pharmacy education leading to competent outcomes that fulfil community needs. The faculty of pharmacy at LIMU is offering a Bachelor of Pharmacy degree. It has also adopted the 'Pharm D' programme in 2016 as one of its undergraduate degrees and hence this faculty underwent major curricular development in order to achieve this goal (Bukhatwa, \& Elfakhri, n.d.).

In its report on pharmaceutical education, the International Pharmaceutical Federation (FIP) highlighted barriers and challenges that are facing the application of high-quality pharmaceutical education in developing countries (FIP, 2013). These barriers include:

\section{i.lack of good infrastructure \\ ii.poor access to teaching resources \\ iii.lack of faculty staff members' development and research conduct, and most importantly}

iv.the political situation of the country

These same barriers are standing in the way of any progress in public pharmaceutical education in Libya.

The aim of this study is to evaluate pharmacy education in the state of Libya through investigating its status using the FIP-Quality Assurance (FIP-QA) educational standards framework. The study findings can help provide practical guidance to facilitate the establishment of quality assurance systems and standards in the countries that lack formal QA system. The framework is intended to be a foundation that can be adapted and built upon to suit national needs, systems, and conditions, and it focuses on the elements that need to be included and how these elements are applied (Rouse, Mestrovic, \& Bruno, 2014). A questionnaire was built using this framework, in order to measure indicators assigned by the five pillars of educational quality. The specific goal of this research study, therefore, is to apply this framework on pharmaceutical education situation in government-based Libyan pharmacy colleges, and use the obtained results as tools to explore ways to advance pharmacy education in the country, hence enhance good practice in line with international standards.

\section{Methods}

The study was carried out through developing a questionnaire based on the 'FIP-QA education framework'. This framework is composed of five sections representing the five pillars of quality education, namely: Context, Structure, Process, Outcomes and Impact. Each section consists of several indicators which were transformed into 


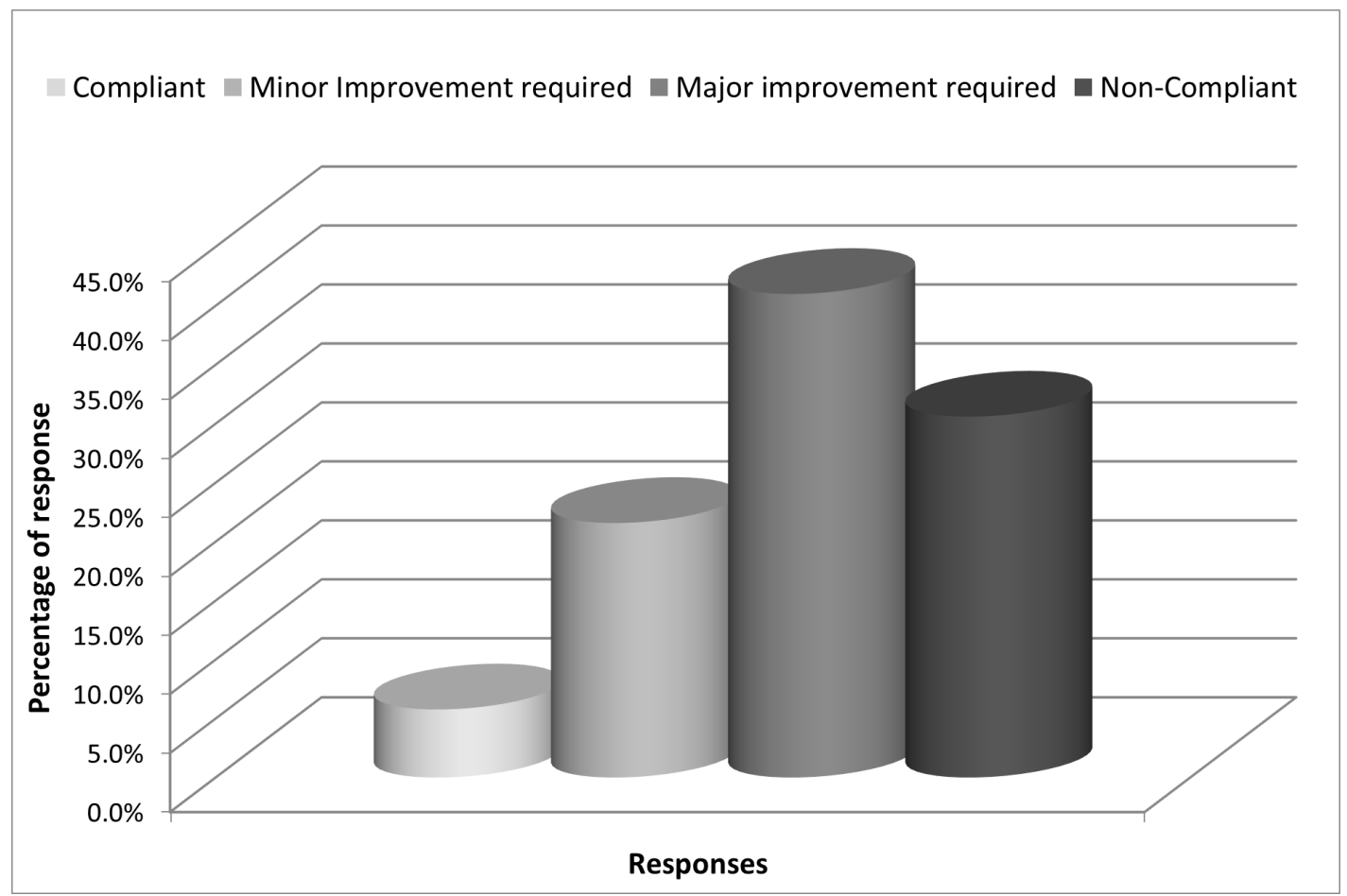

Figure 1: The overall average responses to all indicators of pharmacy education in Libya

questions with four answers to choose from. These choices were:

1) compliance with indicator

2) minor improvement required

3) major improvement required

4) noncompliance

The answers were assigned numbered values from (1 to 4 ) on a Likert scale in the same order above for statistical analysis purposes. 71 indicators were assembled in the form of questions according to the five pillars of the above mentioned QA framework. The questions were translated into the Arabic language to facilitate full comprehension; the pilot study was conducted by directing the questionnaire to five selected participants, who have full knowledge about QA in higher education to answer the survey for the purpose of face validity (Bolarinwa, 2015). The questionnaire was further tested for reliability and validity through applying Cronbach Alpha test using SPSS software version 22 . The finalised questionnaire was sent to 50 faculty members including the deans of eight government-supported faculties of pharmacy in the State of Libya. The selected members were mostly Ph.D. holders and/or have at least ten years of academic experience. The designed questionnaire was distributed through email, and with direct contact with the targeted sample. Data was collected throughout three months during 2018 and quantitative statistical analysis techniques such as mean percentages and frequency distributions were employed. The results were summarised into tables and charts so that meaningful interpretation of results could be made to draw conclusions and implications.

\section{Results}

Applying Cronbach's Alpha to the prepared questionnaire has resulted in a score of 0.94 which indicated that the questionnaire is highly reliable and valid to be used in this investigation. Responses to input questions, which were assembled according to each of the five pillars of quality, are shown in Tables $\mathrm{I}$ to $\mathrm{V}$ and the overall statistical analysis of the Likert scale mean of the five QA sections is represented by Table VI.

A response rate of $84.0 \%$ (Please provide to 1 decimal place) was achieved, as 42 participants answered the questionnaire. Statistical means were calculated for the answers to each pillar, as seen in Table VI. Average calculated means of the five sections were $2.96 \pm 0.531$. Figure 1 represents the overall average responses to all QA indicators of pharmacy education in the state of Libya. Most responses to the sections of context, structure and process questions (see Tables I, II and III) showed that the context, structure, and the process of pharmacy education need major improvement (with an average mean close to 3).

Approximately $27.9 \%$ of the answers showed that the context of pharmacy education (Table I) was non- 
Table I: Responses to QA indicators for pharmacy education context in Libya

\begin{tabular}{|c|c|c|c|c|c|c|c|c|c|c|c|}
\hline \multirow[t]{2}{*}{ Indicator Number } & \multicolumn{2}{|c|}{ Compliant } & \multicolumn{2}{|c|}{$\begin{array}{c}\text { Minor Improvement } \\
\text { Required }\end{array}$} & \multicolumn{2}{|c|}{$\begin{array}{l}\text { Major Improvement } \\
\text { Required }\end{array}$} & \multicolumn{2}{|c|}{ Non-Compliant } & \multirow[t]{2}{*}{ Mean } & \multirow[t]{2}{*}{$\begin{array}{l}\text { Standard } \\
\text { Deviation }\end{array}$} & \multirow[t]{2}{*}{ Variance } \\
\hline & $\mathrm{n}$ & $\%$ & $n$ & $\%$ & $\mathrm{n}$ & $\%$ & $n$ & $\%$ & & & \\
\hline $\begin{array}{l}\text { 1.The mission and goals of the } \\
\text { school reflect and consider the } \\
\text { national environment needs and } \\
\text { priorities }\end{array}$ & 1 & 2.4 & 12 & 29.3 & 21 & 51.2 & 7 & 17.1 & 2.83 & 0.738 & 0.545 \\
\hline $\begin{array}{l}\text { 2. The mission and goals of the } \\
\text { school are aligned with the } \\
\text { profession wide vision for } \\
\text { pharmacy practice and } \\
\text { education }\end{array}$ & 1 & 2.4 & 14 & 34.1 & 18 & 43.9 & 8 & 19.5 & 2.80 & 0.782 & 0.611 \\
\hline $\begin{array}{l}\text { 3. The mission and goals of the } \\
\text { school are aligned with the } \\
\text { mission and goals of the } \\
\text { university }\end{array}$ & 6 & 14.6 & 13 & 31.7 & 19 & 46.3 & 3 & 7.3 & 2.46 & 0.840 & 0.705 \\
\hline $\begin{array}{l}\text { 4. The mission, goals, and values } \\
\text { of the school are developed with } \\
\text { input from key stakeholders }\end{array}$ & 3 & 7.3 & 7 & 17.1 & 12 & 29.3 & 19 & 46.3 & 3.15 & 0.963 & 0.928 \\
\hline $\begin{array}{l}\text { 5. The educational programme is } \\
\text { designed and delivered based on } \\
\text { national and professional needs } \\
\text { and priorities }\end{array}$ & 0 & 0 & 7 & 17.1 & 19 & 46.3 & 15 & 36.6 & 3.20 & 0.715 & 0.511 \\
\hline $\begin{array}{l}\text { 6. Changes in science practice } \\
\text { and regulation influence the } \\
\text { content design and delivery of } \\
\text { the programme }\end{array}$ & 6 & 14.6 & 9 & 22.0 & 11 & 26.8 & 15 & 36.6 & 2.85 & 1.085 & 1.178 \\
\hline $\begin{array}{l}\text { 7. Curricular changes are visible } \\
\text { consensus based and aligned } \\
\text { with changes impacting the } \\
\text { pharmacy profession }\end{array}$ & 2 & 4.9 & 8 & 19.5 & 12 & 29.3 & 19 & 46.3 & 3.17 & 0.919 & 0.845 \\
\hline $\begin{array}{l}\text { 8. The educational programme } \\
\text { provides national and } \\
\text { international perspectives on the } \\
\text { topics being taught }\end{array}$ & 2 & 4.9 & 7 & 17.1 & 17 & 41.5 & 15 & 36.6 & 3.10 & 0.860 & 0.740 \\
\hline $\begin{array}{l}\text { 9. The school implements } \\
\text { strategies and programmes to } \\
\text { broaden the scientific and } \\
\text { professional horizons of students }\end{array}$ & 3 & 7.3 & 3 & 7.3 & 23 & 56.1 & 12 & 29.3 & 3.07 & 0.818 & 0.670 \\
\hline $\begin{array}{l}\text { 10. The school provides and/or } \\
\text { supports the delivery of } \\
\text { educational programmes to its } \\
\text { graduates and other pharmacy } \\
\text { professionals in the form of CE } \\
\text { (Continuous education) and CPD } \\
\text { (continuous professional } \\
\text { development) activities to } \\
\text { inform and influence pharmacy } \\
\text { practice }\end{array}$ & 5 & 12.1 & 1 & 2.4 & 15 & 36.6 & 20 & 48.8 & 3.22 & 0.988 & 0.976 \\
\hline $\begin{array}{l}\text { 11. The school's commitment to } \\
\text { the generation, dissemination } \\
\text { and application of new } \\
\text { knowledge is evident and } \\
\text { demonstrated by productive } \\
\text { research publications and other } \\
\text { scholarly activities }\end{array}$ & 5 & 12.2 & 7 & 17.1 & 22 & 53.7 & 7 & 17.1 & 2.76 & 0.888 & 0.789 \\
\hline $\begin{array}{l}\text { 12. The school embraces the } \\
\text { obligation to be socially } \\
\text { accountable and strives to } \\
\text { address national and community } \\
\text { needs through its educational, } \\
\text { research and service activities }\end{array}$ & 3 & 7.3 & 5 & 12.2 & 27 & 65.9 & 6 & 14.6 & 2.88 & 0.748 & 0.560 \\
\hline $\begin{array}{l}\text { 13. The school provides and } \\
\text { supports projects and activities } \\
\text { that bring about positive } \\
\text { changes in society }\end{array}$ & 2 & 4.9 & 9 & 22.0 & 27 & 65.9 & 3 & 7.3 & 2.76 & 0.663 & 0.788 \\
\hline
\end{tabular}


Table II: Responses to QA indicators for pharmacy education structure in Libya

\begin{tabular}{|c|c|c|c|c|c|c|c|c|c|c|c|}
\hline \multirow[t]{2}{*}{ Indicator Number } & \multicolumn{2}{|c|}{ Compliant } & \multicolumn{2}{|c|}{$\begin{array}{c}\text { Minor Improvement } \\
\text { Required }\end{array}$} & \multicolumn{2}{|c|}{$\begin{array}{c}\text { Major Improvement } \\
\text { Required }\end{array}$} & \multicolumn{2}{|c|}{$\begin{array}{l}\text { Non- } \\
\text { Compliant }\end{array}$} & \multirow[t]{2}{*}{ Mean } & \multirow[t]{2}{*}{$\begin{array}{l}\text { Standard } \\
\text { Deviation }\end{array}$} & \multirow[t]{2}{*}{ Variance } \\
\hline & $\mathrm{n}$ & $\%$ & $\mathrm{n}$ & $\%$ & $\mathrm{n}$ & $\%$ & $\mathrm{n}$ & $\%$ & & & \\
\hline $\begin{array}{l}\text { 14. The director of the school has appropriate } \\
\text { qualifications and experiences in pharmacy } \\
\text { education to provide strong and visible } \\
\text { leadership and ensure the quality of the } \\
\text { professional degree programme }\end{array}$ & 5 & 12.2 & 16 & 39.0 & 10 & 24.4 & 10 & 24.4 & 2.61 & 0.997 & 0.994 \\
\hline $\begin{array}{l}\text { 15. Members of the school administration have } \\
\text { defined lines of authority and responsibility }\end{array}$ & 3 & 7.3 & 14 & 34.1 & 21 & 51.2 & 3 & 7.3 & 2.59 & 0.741 & 0.549 \\
\hline $\begin{array}{l}\text { 16. Members of the school administration foster } \\
\text { organisational unit development and collegiality, } \\
\text { and appropriately allocate resources }\end{array}$ & 2 & 4.9 & 9 & 22.2 & 21 & 51.2 & 9 & 22.0 & 2.90 & 0.800 & 0.640 \\
\hline $\begin{array}{l}\text { 17. Time, facilities and resources are well } \\
\text { managed }\end{array}$ & 3 & 7.3 & 9 & 22.0 & 20 & 48.8 & 9 & 22.0 & 2.85 & 0.853 & 0.728 \\
\hline $\begin{array}{l}\text { 18. Committees are established to identify and } \\
\text { address key components of the mission and } \\
\text { goals }\end{array}$ & 0 & 0 & 1 & 2.4 & 21 & 51.2 & 19 & 46.3 & 3.44 & 0.550 & 0.302 \\
\hline $\begin{array}{l}\text { 19. The school develops collaborative } \\
\text { relationships and partnerships with stakeholders } \\
\text { (internal and external) }\end{array}$ & 1 & 2.4 & 6 & 14.6 & 26 & 63.4 & 8 & 19.5 & 3.00 & 0.671 & 0.450 \\
\hline $\begin{array}{l}\text { 20. The school evaluates the outcomes and } \\
\text { impact of collaborative relationships and } \\
\text { partnerships }\end{array}$ & 0 & 0 & 11 & 26.8 & 21 & 51.2 & 9 & 22.0 & 2.95 & 0.705 & 0.498 \\
\hline $\begin{array}{l}\text { 21. Learning objectives of courses are } \\
\text { appropriate to achieve the desired } \\
\text { competencies }\end{array}$ & 3 & 7.3 & 13 & 31.7 & 14 & 34.1 & 11 & 26.8 & 2.80 & 0.928 & 0.861 \\
\hline $\begin{array}{l}\text { 22. Curricular content is well aligned with the } \\
\text { official (legal) scope of practice of pharmacists }\end{array}$ & 1 & 2.4 & 14 & 34.1 & 16 & 39.0 & 10 & 24.4 & 2.85 & 0.823 & 0.678 \\
\hline $\begin{array}{l}\text { 23. The curriculum provides a thorough } \\
\text { foundation (knowledge base) in biomedical, } \\
\text { pharmaceutical, social, behavioural, } \\
\text { administrative and clinical sciences }\end{array}$ & 0 & 0 & 15 & 36.6 & 16 & 39.0 & 10 & 24.4 & 2.88 & 0.781 & 0.610 \\
\hline $\begin{array}{l}\text { 24. Educational activities are based on science, } \\
\text { practice and ethics to address all competency } \\
\text { areas (knowledge, skills, attitudes, values) }\end{array}$ & 2 & 4.9 & 14 & 34.1 & 15 & 36.6 & 10 & 24.4 & 2.80 & 0.872 & 0.761 \\
\hline $\begin{array}{l}\text { 25. The school has a sufficient number of } \\
\text { qualified full-time academic (including } \\
\text { pharmacy trained) and other staff to effectively } \\
\text { deliver and evaluate the professional degree } \\
\text { programme }\end{array}$ & 0 & 0 & 11 & 26.8 & 12 & 29.3 & 18 & 43.9 & 3.17 & 8.34 & 0.695 \\
\hline $\begin{array}{l}\text { 26. The school identifies trained pharmacist } \\
\text { preceptors who have the expertise, experience } \\
\text { and commitment to facilitate learning and } \\
\text { evaluate the achievement of required } \\
\text { competencies by students }\end{array}$ & 0 & 0 & 7 & 17.1 & 15 & 36.6 & 19 & 46.3 & 3.29 & 0.750 & 0.562 \\
\hline $\begin{array}{l}\text { 27. The school has established and } \\
\text { implemented criteria for the selection of an } \\
\text { adequate number and mix of pharmacy } \\
\text { practice facilities and sites for student } \\
\text { 'experimental education' }\end{array}$ & 0 & 0 & 12 & 29.3 & 13 & 31.7 & 16 & 39.0 & 3.10 & 0.831 & 0.690 \\
\hline $\begin{array}{l}\text { 28. The physical facilities are safe, well } \\
\text { maintained, and adequately equipped for } \\
\text { teaching learning and research }\end{array}$ & 4 & 9.8 & 4 & 9.8 & 4 & 9.8 & 29 & 70.7 & 3.41 & 1.024 & 1.049 \\
\hline $\begin{array}{l}\text { 29. The school has a broad base of financial } \\
\text { support to provide a stable environment for the } \\
\text { delivery and ongoing development and growth } \\
\text { of the programme }\end{array}$ & 1 & 2.4 & 4 & 9.8 & 6 & 14.6 & 30 & 73.2 & 3.59 & 0.774 & 0.599 \\
\hline $\begin{array}{l}\text { 30. The school ensures access for all academic } \\
\text { staff, preceptors, and students to a } \\
\text { comprehensive library and other learning/ } \\
\text { educational resources, including electronic and } \\
\text { web-based resources }\end{array}$ & 4 & 9.8 & 1 & 2.4 & 9 & 22.0 & 27 & 65.9 & 3.44 & 0.950 & 0.902 \\
\hline $\begin{array}{l}\text { 31. The school's physical facilities include } \\
\text { simulated pharmacy practice settings where the } \\
\text { school organise active learning and performance } \\
\text { assessment supervised by preceptors and/or } \\
\text { academic staff with appropriate pharmacy } \\
\text { practice experience }\end{array}$ & 2 & 4.9 & 1 & 2.4 & 22 & 53.7 & 16 & 39.0 & 3.27 & 0.742 & 0.551 \\
\hline
\end{tabular}


Table III: Responses to QA indicators for pharmacy education process in Libya

\begin{tabular}{|c|c|c|c|c|c|c|c|c|c|c|c|}
\hline \multirow[t]{2}{*}{ Indicator Number } & \multicolumn{2}{|c|}{ Compliant } & \multicolumn{2}{|c|}{$\begin{array}{l}\text { Minor Improvement } \\
\text { Required }\end{array}$} & \multicolumn{2}{|c|}{$\begin{array}{l}\text { Major Improvement } \\
\text { Required }\end{array}$} & \multicolumn{2}{|c|}{$\begin{array}{c}\text { Non- } \\
\text { Compliant }\end{array}$} & \multirow[t]{2}{*}{ Mean } & \multirow[t]{2}{*}{$\begin{array}{l}\text { Standard } \\
\text { Deviation }\end{array}$} & \multirow[t]{2}{*}{ Variance } \\
\hline & $\mathrm{n}$ & $\%$ & $\mathrm{n}$ & $\%$ & $\mathrm{n}$ & $\%$ & $\mathrm{n}$ & $\%$ & & & \\
\hline $\begin{array}{l}\text { 32. The strategic plan is developed based on an } \\
\text { examination of the current environment, } \\
\text { assessing strengths, weaknesses opportunities, } \\
\text { and threats relevant to the school }\end{array}$ & 2 & 4.9 & 3 & 7.3 & 17 & 41.5 & 19 & 46.3 & 3.29 & 0.814 & 0.662 \\
\hline $\begin{array}{l}\text { 33. The strategic plan is developed and adopted } \\
\text { with input from key stakeholders (internal and } \\
\text { external) }\end{array}$ & 3 & 7.3 & 3 & 7.3 & 13 & 31.7 & 22 & 53.7 & 3.32 & 0.907 & 0.822 \\
\hline $\begin{array}{l}\text { 34. Enrolment of students is transparent and } \\
\text { well organised }\end{array}$ & 4 & 9.8 & 20 & 48.8 & 12 & 29.3 & 5 & 12.2 & 2.44 & 0.838 & 0.702 \\
\hline $\begin{array}{l}\text { 35. Enrolment of students is aligned with the } \\
\text { resources of the school and university }\end{array}$ & 3 & 7.3 & 17 & 41.5 & 18 & 43.9 & 3 & 7.3 & 2.51 & 0.746 & 0.556 \\
\hline $\begin{array}{l}\text { 36. Enrolment of students is aligned with } \\
\text { national needs }\end{array}$ & 2 & 4.9 & 1 & 2.4 & 8 & 19.5 & 20 & 73.2 & 3.61 & 0.771 & 0.594 \\
\hline $\begin{array}{l}\text { 37. Academic policies and procedures are } \\
\text { defined and available for all students and } \\
\text { prospective students }\end{array}$ & 2 & 4.9 & 9 & 22.0 & 17 & 41.5 & 13 & 31.7 & 3.00 & 0.866 & 0.750 \\
\hline $\begin{array}{l}\text { 38. Comprehensive student services are } \\
\text { available to all students, assuring individual } \\
\text { attention, guidance and support }\end{array}$ & 1 & 2.4 & 15 & 36.6 & 16 & 39.0 & 9 & 22.0 & 2.80 & 0.813 & 0.661 \\
\hline $\begin{array}{l}\text { 39. The school considers student perspectives } \\
\text { and includes student representation on } \\
\text { appropriate committees, including curriculum } \\
\text { and assessment and evaluation activities }\end{array}$ & 3 & 7.3 & 6 & 14.6 & 9 & 22.0 & 23 & 56.1 & 3.27 & 0.975 & 0.951 \\
\hline $\begin{array}{l}\text { 40. Curricula revision ensures the overall } \\
\text { integrity of curriculum, avoiding curricular } \\
\text { overload, redundancy, dilution of focus and } \\
\text { insufficient depth of coverage for essential } \\
\text { components of the curriculum }\end{array}$ & 0 & 0 & 10 & 24.4 & 20 & 48.8 & 11 & 26.8 & 3.02 & 0.724 & 0.524 \\
\hline $\begin{array}{l}\text { 41. Students are actively encouraged and } \\
\text { supported to assume responsibility for their } \\
\text { own learning including the self-identification of } \\
\text { learning needs and gaps }\end{array}$ & 0 & 0 & 11 & 26.8 & 22 & 53.7 & 8 & 19.5 & 2.93 & 0.685 & 0.470 \\
\hline $\begin{array}{l}\text { 42. Educational content appropriately addresses } \\
\text { traditional, contemporary and future practice }\end{array}$ & 2 & 4.9 & 15 & 36.6 & 18 & 43.9 & 6 & 14.6 & 2.68 & 0.789 & 0.622 \\
\hline $\begin{array}{l}\text { 43. Contents and methodologies prepare } \\
\text { students for practice in a variety of practice } \\
\text { settings }\end{array}$ & 0 & 0 & 9 & 22.0 & 21 & 51.2 & 11 & 26.8 & 3.05 & 0.705 & 0.498 \\
\hline $\begin{array}{l}\text { 44. Teaching and learning methodologies } \\
\text { account for and cater to diverse learners, } \\
\text { including different learning styles and } \\
\text { preferences of students }\end{array}$ & 0 & 0 & 12 & 29.3 & 19 & 46.3 & 10 & 24.4 & 2.95 & 0.740 & 0.548 \\
\hline $\begin{array}{l}\text { 45. Materials and resources are provided to the } \\
\text { students (or cited) to enhance understanding } \\
\text { and application of the educational material in } \\
\text { practice }\end{array}$ & 3 & 7.3 & 5 & 12.2 & 21 & 51.2 & 12 & 29.3 & 3.02 & 0.851 & 0.724 \\
\hline $\begin{array}{l}\text { 46. The programme provides opportunities for } \\
\text { inter-professional education and activities }\end{array}$ & 2 & 4.9 & 3 & 7.3 & 11 & 26.8 & 25 & 61.0 & 3.44 & 0.838 & 0.702 \\
\hline $\begin{array}{l}\text { 47. The programme offers a broad range of } \\
\text { elective subjects }\end{array}$ & 0 & 0 & 6 & 14.6 & 22 & 53.7 & 13 & 31.7 & 3.17 & 0.667 & 0.445 \\
\hline $\begin{array}{l}\text { 48. Curricular content is evidence based, } \\
\text { balanced, objective, and unbiased }\end{array}$ & 2 & 4.9 & 3 & 7.3 & 18 & 43.9 & 18 & 43.9 & 3.27 & 0.807 & 0.651 \\
\hline $\begin{array}{l}\text { 49. The educational activities use active learning } \\
\text { strategies and promote problem solving and } \\
\text { critical thinking skills }\end{array}$ & 0 & 0 & 10 & 24.4 & 26 & 63.4 & 5 & 12.2 & 2.88 & 0.600 & 0.360 \\
\hline $\begin{array}{l}\text { 50. The school has effective measures and } \\
\text { processes to evaluate the achievement of each } \\
\text { stated learning objective and competency } \\
\text { development goal by all graduates }\end{array}$ & 2 & 4.9 & 2 & 2.9 & 13 & 31.7 & 24 & 58.5 & 3.44 & 0.808 & 0.652 \\
\hline $\begin{array}{l}\text { 51. Student assessment criteria and } \\
\text { methodologies are defined and implemented, } \\
\text { serving as a basis for future curricular } \\
\text { improvement }\end{array}$ & 1 & 2.4 & 12 & 29.3 & 21 & 51.2 & 6 & 14.6 & 2.80 & 0.723 & 0.523 \\
\hline $\begin{array}{l}\text { 52. The evaluation process for academic and } \\
\text { other staff involves self-assessment and includes } \\
\text { input from peers, supervisors, and students }\end{array}$ & 3 & 7.3 & 8 & 19.5 & 12 & 29.3 & 18 & 43.9 & 3.10 & 0.970 & 0.940 \\
\hline
\end{tabular}


Table IV: Responses to QA indicators for pharmacy education outcomes in Libya

\begin{tabular}{|c|c|c|c|c|c|c|c|c|c|c|c|}
\hline \multirow[t]{2}{*}{ Indicator Number } & \multicolumn{2}{|c|}{ Compliant } & \multicolumn{2}{|c|}{$\begin{array}{c}\text { Minor Improvement } \\
\text { Required }\end{array}$} & \multicolumn{2}{|c|}{$\begin{array}{c}\text { Major Improvement } \\
\text { Required }\end{array}$} & \multicolumn{2}{|c|}{ Non-Compliant } & \multirow[t]{2}{*}{ Mean } & \multirow[t]{2}{*}{$\begin{array}{l}\text { Standard } \\
\text { Deviation }\end{array}$} & \multirow[t]{2}{*}{ Variance } \\
\hline & $\mathrm{n}$ & $\%$ & $n$ & $\%$ & $n$ & $\%$ & $\mathrm{n}$ & $\%$ & & & \\
\hline $\begin{array}{l}\text { 53. Learning outcomes are } \\
\text { competency based, specific and } \\
\text { measurable }\end{array}$ & 2 & 4.9 & 9 & 22.0 & 15 & 36.6 & 15 & 36.6 & 3.05 & 0.893 & 0.798 \\
\hline $\begin{array}{l}\text { 54. Validated measures are used } \\
\text { to evaluate the extent to which } \\
\text { the desired outcomes of the } \\
\text { professional degree programme } \\
\text { (including assessments of } \\
\text { student learning and evaluation } \\
\text { of the effectiveness of } \\
\text { curriculum) are being achieved }\end{array}$ & 4 & 9.8 & 13 & 31.7 & 14 & 34.1 & 10 & 24.4 & 2.73 & 0.949 & 0.901 \\
\hline $\begin{array}{l}\text { 55. Evaluation of learning } \\
\text { outcomes includes all } \\
\text { competencies (knowledge skills } \\
\text { and attitudes) }\end{array}$ & 1 & 2.4 & 11 & 26.8 & 24 & 58.5 & 5 & 12.2 & 2.80 & 0.679 & 0.461 \\
\hline $\begin{array}{l}\text { 56. Competencies to be } \\
\text { achieved by graduates are } \\
\text { clearly stated by the schools }\end{array}$ & 1 & 2.4 & 9 & 22.0 & 23 & 56.1 & 8 & 19.5 & 2.93 & 0.721 & 0.520 \\
\hline $\begin{array}{l}\text { 57. Competencies to be } \\
\text { achieved by graduates are } \\
\text { aligned with national and global } \\
\text { needs and trends }\end{array}$ & 1 & 2.4 & 14 & 34.1 & 21 & 51.2 & 5 & 12.2 & 2.73 & 0.708 & 0.501 \\
\hline $\begin{array}{l}\text { 58. Students develop new } \\
\text { knowledge and skills to improve } \\
\text { patient and population health }\end{array}$ & 2 & 4.9 & 7 & 17.1 & 16 & 39.0 & 16 & 39.0 & 3.12 & 0.872 & 0.760 \\
\hline $\begin{array}{l}\text { 59. Students adopt an ethical } \\
\text { approach to develop their self- } \\
\text { awareness and values }\end{array}$ & 5 & 12.2 & 4 & 34.1 & 19 & 46.3 & 3 & 7.3 & 2.49 & 0.810 & 0.656 \\
\hline $\begin{array}{l}\text { 60. The school assesses student } \\
\text { professionalism behaviour and } \\
\text { attitudes }\end{array}$ & 4 & 9.8 & 4 & 9.8 & 22 & 53.7 & 11 & 26.8 & 2.98 & 0.880 & 0.774 \\
\hline $\begin{array}{l}\text { 61. Through the research } \\
\text { publications and other scholarly } \\
\text { activities of its academics staff } \\
\text { and students, the school } \\
\text { contributes to the generation, } \\
\text { dissemination and application of } \\
\text { new knowledge }\end{array}$ & 5 & 12.2 & 7 & 17.1 & 19 & 46.3 & 10 & 24.4 & 2.83 & 0.946 & 0.895 \\
\hline $\begin{array}{l}\text { 62. The school supports } \\
\text { initiatives and projects that serve } \\
\text { the health-related needs of the } \\
\text { population and advance } \\
\text { pharmacy practice models in } \\
\text { community pharmacy and } \\
\text { hospital settings }\end{array}$ & 10 & 24.4 & 13 & 31.7 & 14 & 34.1 & 4 & 9.8 & 2.29 & 0.955 & 0.912 \\
\hline $\begin{array}{l}\text { 63. The school, with the support } \\
\text { of the university, establishes } \\
\text { productive and effective } \\
\text { collaboration and networks with: } \\
\text { other schools universities, the } \\
\text { pharmacy practice community, } \\
\text { the pharmaceutical industry, } \\
\text { national and international } \\
\text { organisations, the government } \\
\text { and other appropriate partners. }\end{array}$ & 8 & 19.5 & 19 & 46.3 & 7 & 17.1 & 7 & 17.1 & 2.32 & 0.986 & 0.972 \\
\hline
\end{tabular}


Table V: Responses to QA indicators for pharmacy education impact in Libya

\begin{tabular}{|c|c|c|c|c|c|c|c|c|c|c|c|}
\hline \multirow[t]{2}{*}{ Indicator Number } & \multicolumn{2}{|c|}{ Compliant } & \multicolumn{2}{|c|}{$\begin{array}{l}\text { Minor Improvement } \\
\text { Required }\end{array}$} & \multicolumn{2}{|c|}{$\begin{array}{l}\text { Major Improvement } \\
\text { Required }\end{array}$} & \multicolumn{2}{|c|}{ Non-Compliant } & \multirow[t]{2}{*}{ Mean } & \multirow[t]{2}{*}{$\begin{array}{l}\text { Standard } \\
\text { Deviation }\end{array}$} & \multirow[t]{2}{*}{ Variance } \\
\hline & $\mathrm{n}$ & $\%$ & $n$ & $\%$ & $n$ & $\%$ & $\mathrm{n}$ & $\%$ & & & \\
\hline $\begin{array}{l}\text { 64. Learning leads to behaviour } \\
\text { and performance changes by } \\
\text { graduates }\end{array}$ & 1 & 2.4 & 10 & 24.4 & 22 & 53.7 & 8 & 19.5 & 2.90 & 0.735 & 0.540 \\
\hline $\begin{array}{l}65 . \text { The students and graduates } \\
\text { feel honour and pride in } \\
\text { belonging to the international } \\
\text { pharmacy community and are } \\
\text { aware they they are a direct } \\
\text { reflection on the profession }\end{array}$ & 1 & 2.4 & 9 & 22.0 & 25 & 61.0 & 6 & 14.6 & 2.88 & 0.678 & 0.460 \\
\hline $\begin{array}{l}\text { 66. New projects, services or } \\
\text { activities are visible in pharmacy } \\
\text { practice as a result of the impact } \\
\text { of students and graduates } \\
\text { knowledge, skills and motivation }\end{array}$ & 1 & 2.4 & 3 & 7.3 & 21 & 51.2 & 16 & 39.0 & 3.27 & 0.708 & 0.501 \\
\hline $\begin{array}{l}\text { 67. Advocacy and impact on the } \\
\text { development of the profession is } \\
\text { achieved through the leadership } \\
\text { of the school, its academic staff } \\
\text { and graduates who are agents of } \\
\text { change }\end{array}$ & 1 & 2.4 & 9 & 22.0 & 20 & 48.8 & 11 & 26.8 & 3.00 & 0.775 & 0.600 \\
\hline $\begin{array}{l}\text { 68. Innovations and change that } \\
\text { address or solve national and/or } \\
\text { international healthcare-related } \\
\text { needs and priorities are } \\
\text { achieved }\end{array}$ & 6 & 14.6 & 7 & 17.1 & 10 & 24.4 & 18 & 43.9 & 2.98 & 1.107 & 1.224 \\
\hline $\begin{array}{l}69 . \text { Ethical aspects, such as } \\
\text { building the self-image of } \\
\text { pharmacists, enhancing } \\
\text { professional autonomy and } \\
\text { personal development, are } \\
\text { visible as a result of the } \\
\text { programme }\end{array}$ & 8 & 19.5 & 6 & 14.6 & 13 & 31.7 & 14 & 34.1 & 2.80 & 1.123 & 1.261 \\
\hline $\begin{array}{l}\text { 70. The school has developed } \\
\text { and adopted an 'oath of a } \\
\text { pharmacist' to be taken by } \\
\text { students before they enter into } \\
\text { practice }\end{array}$ & 2 & 4.9 & 13 & 31.7 & 14 & 34.1 & 12 & 29.3 & 2.88 & 0.900 & 0.810 \\
\hline $\begin{array}{l}\text { 71. Pharmacy students and new } \\
\text { pharmacy graduates promise, in } \\
\text { public, before their mentors and } \\
\text { peers, to follow the highest } \\
\text { standards of professional } \\
\text { practice and ethics and commit } \\
\text { to lifelong learning to maintain } \\
\text { and enhance their competence }\end{array}$ & 3 & 7.3 & 7 & 17.1 & 20 & 48.8 & 11 & 26.8 & 2.95 & 0.865 & 0.550 \\
\hline
\end{tabular}

Table VI: Statistical analysis representing the Likert scale mean of the QA sections

\begin{tabular}{lrlll}
\hline Section & $\mathbf{n} *$ & Mean score & Standard Deviation & $\begin{array}{l}\text { Standard error of } \\
\text { the mean }\end{array}$ \\
\hline Context & 42 & 2.96 & 0.526 & 0.0832 \\
Structure & 42 & 3.07 & 0.522 & 0.0825 \\
Process & 42 & 3.07 & 0.446 & 0.0706 \\
Outcomes & 42 & 2.88 & 0.545 & 0.0861 \\
Impact & 42 & 2.82 & 0.617 & 0.0975 \\
\hline
\end{tabular}

* Number of participants compliant with international standards and about $45.6 \%$ suggested that the context needs major improvement (total of $7.5 \%$ ). The responses concerning the structure of education (Table II) indicated that the respondents' opinion was mainly restricted to the two answers that correspond to 'major improvement required' and 'noncompliance' with the indicators of quality in all colleges of pharmacy in the country with an average mean of $3.07 \pm 0.522$. The results of investigating the educational process suggested that $74.8 \%$ of participants responded that it is either non- 
compliant with standards or needed great improvement (Table III). A high percentage of respondents (73.2\%) to indicators concerning learning outcomes such as competencies, suggested that these were not clearly defined, thus cannot be evaluated and validated. Of those questioned, $78.0 \%$ reported that students have difficulty in developing new knowledge and skills related to improving patient health.

The contribution of the Libyan colleges to the generation and dissemination of new knowledge was considered weak and incompetent, as has most of the questioned faculty members answered. In addition, $43.9 \%$ of the participants felt that the support of Libyan faculties of pharmacy for initiatives and projects, which advance pharmacy practice models in community pharmacy and hospital settings, is poor. Only a small percentage (fewer than $10.0 \%$ ) of those questioned reported that these colleges, with the support of their universities, established productive and effective collaboration with other stakeholders.

\section{Discussion}

\section{Context}

Table I summarises the results of evaluating the context of pharmacy education in the State of Libya. Questions 1 to 4 are concerned with the 'mission' and 'goals' of the college and its relevance to the profession and pharmacy practice, national needs, and its alignment with university and stakeholders' views. The responses to these questions indicated that the mission, goals, and values of the Libyan colleges of pharmacy require some adjustments in several matters related to internal and external factors. For instance, the mission and goals should be more concerned with the way of teaching, research and scholar activity, service to the society, participation in pharmacy practice, and advancement of the profession. Moreover, the mission and goals should mirror the national needs and be aligned with the profession's wide vision for pharmacy education and practice. This change will ensure that graduates are appropriately educated and trained to deliver pharmaceutical services that meet current and prospective social needs and expectations. The mean value of the Likert scale \pm SD for the first four answers is equal to $2.81 \pm 0.830$, which indicated that the 'mission' and 'goals' of many Libyan pharmacy colleges and their relevance to the profession and pharmacy practice need great improvement. Questions 5 through 13 dealt with the educational programme and its relation to several indicators such as whether the programme was designed according to national needs and pharmacy practice. Most participants selected the answers that correspond to either non-compliance with indicator $30.3 \%$ ) or 'major improvement is required' (46.3\%). Approximately $85.0 \%$ of staff members were not satisfied with the strategies or programmes of their colleges to broaden the scientific and professional horizons of their students. Answers to Q10 indicated that $85.4 \%$ of responses correspond to 'noncompliance' and 'major improvement required' choices, which suggest that pharmacy colleges play small role in the delivery of continuous education (CE) and continuous professional development (CPD) to pharmacy college graduates and pharmacy technicians nationwide. However, nearly $29.0 \%$ of the participants believe that their colleges need only simple enhancement, or that their college is completely committed to applying new evidence-based knowledge in research and scientific activities.

When it came to answering question $12,80.5 \%$ of the contributors believed that the behaviour of the colleges toward social accountability needs great amendments. Some of the respondents (14.6\%) even thought that the colleges were not compliant with social accountability. In the optional, additional comments section of the survey, some argued that these colleges should be more responsive to the healthcare-related needs and priorities of its community and the nation, and should strive to address national and community needs through its educational, research, and service activities.

\section{Structure}

Table II summarises the responses of the questionnaire which deals with structure of the education process. Answers to Q14 suggested that approximately $50.0 \%$ of staff members believe that the directors of the colleges (such as the dean or equivalent) do not provide strong or visible leadership to the college of pharmacy, and do not assume primary responsibility for ensuring the quality of the professional degree programme.

In response to Q15, $58.5 \%$ of participants think that members of the college administration should have more defined lines of authority and responsibility and according to Q16, 73.2\% advised the leadership of the colleges to foster organisational unit development and collegiality, and appropriately allocate resources. The majority of respondents (70.8\%) to Q17 agreed that management of time and facilities is poor, and thus requires great improvement. Responses to Q18 which was concerned with establishing committees to identify and address key components of the mission and goals, suggests that these 
committees are lacking or may be even absent in some Libyan pharmacy colleges. $46.3 \%$ of the answers indicated that this requirement (indicator) is not compliant with the regulation and $51.2 \%$ suggested that it may need great enhancement. Additionally, more than $70.0 \%$ of replies to Q19 and Q20 pointed out that there is a poor collaboration between the college and university administration, among different colleges or departments at the same university, and between colleges and stakeholders.

When questioned about designing of the curriculum in pharmacy colleges (Q21-24), answers pointed out that pharmacy curriculum need great improvement in order to comply with international regulations (as the mean value of $2.83 \pm 0.85$ indicated). This means that the curriculum is still far from identifying the educational outcomes and competencies that graduates must achieve to address current and future national health needs. These results suggested that the curricula for the current professional degree programmes are still far from meeting the goal of supporting the preparation of graduates with the competencies needed to practice in patient-centred settings in order to be leaders and agents of change. $34.1 \%$ of the questioned faculty members in the survey, however, claimed that the current curriculum need only minor improvement to provide a thorough foundation in the biomedical, pharmaceutical, social, behavioural, administrative, and clinical sciences. In response to Q25, nearly $50.0 \%$ of participants believe that pharmacy colleges cannot provide effective professional programmes to their students as they are understaffed, and do not have enough qualified, full-time academicians (especially those who were educated and trained through pharmacy colleges). The previous finding was further emphasised by the answers to the next portion of the questionnaire which suggested that the colleges lack trained and experienced preceptors who have the expertise and commitment to facilitate learning and evaluate the achievement of the required competencies by students. Moreover, pharmacy practice sites and facilities associated with these colleges for training purposes are practically unavailable and must be provided. In addition to the physical facilities, which generally do not comply with international standards meaning they fail to meet the required teaching standards, were mentioned as issues by $78.0 \%$ of the answers to Q26-28.

Assessing the financial support for these colleges indicated that $73.2 \%$ of respondents selected the 'non-compliant' option; this shows that Libyan colleges of pharmacy have a low stream of financial support which makes them unable to provide a stable environment for the delivery of, and continuing development and growth of the programme. Little access to academic staff, clinical preceptors, and students to a comprehensive library were further issues as was stated by $65.9 \%$ of the respondents. Besides, only a minority of these colleges contain simulated pharmacy practice settings, thus, most of the investigated faculties cannot organise active learning or perform the assessment for students in an appropriate atmosphere (Q29-31).

\section{Process}

When answering Q32 and 33 (Table III), the majority of respondents (close to $85.0 \%$ ) think that the strategic plan in Libyan colleges of pharmacy is fragile and underdeveloped, based on an examination of the current environment and views of key stakeholders. Over $40.0 \%$ of participants in the survey, when answered Q34, reported that enrolment of students lack transparency and is not aligned with the resources of the college, university, or also with national needs. Only $4.9 \%$ of those who answered Q37 suggested that Libyan pharmacy colleges have a defined and available academic policies for all students and prospective students.

In response to Q40, nearly all of those surveyed indicated that curricula revision in Libyan faculties of pharmacy did not occur in alignment with quality standards which are recommended by the FIP. The FIP recommends that the revision must ensure the overall integrity of the curriculum, avoiding curricular overload, redundancy, dilution of focus and insufficient depth of coverage for essential components of the curriculum. The majority of those who responded to Q41 felt that there is not enough encouragement and support for students to assume responsibility for their own learning, including the selfidentification of learning needs and gaps.

Questions 42 to 45 were concerned with curricula, educational content, and teaching methods and how these factors affect the future practice of students in a variety of practice settings. As expected, the responses demonstrated that the educational and curricular content with teaching methods are all either non-compliant with quality standard or need major improvement.

In answering Q46 and 47 more than $80.0 \%$ of the questioned staff members are nearly in complete agreement with the opinion that says that the educational programme is far away from providing opportunities for inter-professional education and away from offering elective subjects for their students. In response to Q48, and as anticipated, according to $43.9 \%$ of the answers, the 
curricular contents require major editing and adjustment to be more evidence-based, balanced, objective, and unbiased. 75.6\% of answers to Q49 suggested that there is no adequate use of the active learning strategies, problem-solving approaches or critical thinking skills. The analysis of Q50 responses confirms that Libyan pharmacy colleges have difficulty in measuring and evaluating the outcomes of each stated learning objective and competency development goal by all graduates. $65.8 \%$ of respondents expressed that there is a weak correlation between the assessment criteria of the students and the development and improvement of the curriculum when answered Q51. Answers to Q52 indicated that the evaluation process for the academic staff members, is distant from the application of self-assessment, assessment of peers and students' estimation.

\section{Outcomes}

Taking a quick look at the results of the three previous sections for the quality measurement of pharmaceutical education in Libya, it is not surprising that the outcomes of pharmaceutical education are weak and need to be improved. And because the educational process is interrelated, if one of the pillars is weakened or disrupted it will certainly affect the entire educational process.

According to $73.2 \%$ of the respondents to Q53 (Table IV), the learning outcomes such as competencies are not compliant or need great improvement to be measured; consequently they are not aligned with national requirements and need to be measured continuously. About $53.6 \%$ of responses indicated that the competencies that graduates must achieve need major improvement and should be clearly identified by the colleges. When answering Q58 and 59, 65.8\% of respondents revealed that students lack new knowledge and skills that help improve patient and population health. Besides, students are not trained to adopt an ethical approach to develop their self-awareness and values.

The contribution of the Libyan colleges in the creation and dissemination of new knowledge, through research publications and other scholarly activities of its academic staff and students, is considered weak and incompetent; as evidenced by the answers of $70.7 \%$ of respondents who chose either 'non-compliant' or need great improvement' when answering Q61. Furthermore, $43.9 \%$ of the participants felt that the support of the Libyan colleges for initiatives and projects that serve the health-related needs of the population, and advance pharmacy practice models in community pharmacy and hospital settings, are disappointing as participants chose either none compliant or major improvement required. By contrast, however, a considerable percentage $(65.8 \%)$ of the respondents reported in Q63 that the Libyan colleges of pharmacy have established productive and effective collaborations and networks with other schools, universities, the pharmacy practice community, the pharmaceutical industry, national and international organisations, the government, and other appropriate partners with the support of their faculties.

\section{Impact}

The impact of long-term education will take many years to be noticed. This impact is certainly dependent on the above mentioned pillars combined. Therefore, it is not surprising that the impact of pharmaceutical education is far from its primary goal of providing the community with proper health care practitioners.

With reference to the responses to Q64 (Table V), it was indicated that the behaviour and performance of the graduates is gloomy and ambiguous as indicated by $53.7 \%$ of the participants who chose the 'need great improvement' option. Answers to Q65 showed that nearly $25.0 \%$ of the students and graduates feel honour and pride in belonging to the international pharmacy community and are aware that they are a direct reflection on the profession. However, more than $70.0 \%$ of the survey respondents who answered Q66-68 believe that students, graduates, and academic staff have a low impact on a wide range of aspects. For example, their impact on pharmacy practice over the years was considered invisible and blurred. The faculty members who participated in this research work have recognised the failure to address and solving the imperfections in providing healthcare-related needs.

Answers to Q70 and 71 indicated that all the Libyan faculties of pharmacy have developed and adopted an 'Oath for Pharmacists' which is recited by graduates who swear to follow the highest standards of professional practice and ethics, and commit to lifelong learning, to maintain and enhance their professional competence.

\section{Conclusion}

The results of this study indicated that the quality of pharmaceutical education in the State of Libya requires great improvement in order to achieve the desired results, and that the current curricula of the approved programmes are still far from achieving the goal of supporting graduates who with necessary competencies 
to exercise new roles in different practice settings. The impact of developing pharmaceutical education in Libya will not occur overnight, although some improvement has started to be seen in major faculties of pharmacy. This is because of the lack of support from government and universities to experienced academic personnel in the field, whom will lead the change in both pharmacy education and pharmacy practice.

It is, however, worth mentioning that the Faculty of Pharmacy at UOT is in the process of revising its curricula. Faculty members at this college have already started adopting new and advanced teaching methods that aim at freeing students from traditional education systems and instating more advanced methods to build skills, attitudes, and knowledge using problem-based learning, interprofessional, and experiential education. Furthermore, the UOT Pharmacy faculty has recently started working towards launching the professional degree (Pharm.D.) which will be established in the coming years and its curricula will be accredited soon.

In conclusion, this study raises several red flags for the health education officials in Libya, and urges them to start making radical changes to pharmacy education, allowing pharmacy programmes can catch up with international counterparts in producing competent pharmacists with the ability to exercise their responsibilities and who will become influential factors and leaders for change. The results of this investigation have the potential to inform the administrators of pharmacy colleges in Libya on areas to reform pharmacy curricula. This may allow for faculties of pharmacy to achieve the primary goal of providing society with healthcare practitioners who respond to the needs of people who use pharmacists' services to provide optimal, evidence-based care and who contribute to health improvement by helping patients with health problems to make the best use of their medicines.

\section{Acknowledgement}

The authors of this article extend their thanks and appreciation to all faculty members of the faculties of pharmacy in Libyan universities who contributed by responding to the questionnaire prepared for this research, and for all their important observations that accompanied this contribution.

\section{References}

1st meeting for the Development Committee of the Faculty of Pharmacy, UOT with all sectors of the Libyan pharmaceutical community. Series of 6 meetings (April - December 2015)

Bolarinwa, O. (2015). Principles and methods of validity and reliability testing of questionnaires used in social and health science researches. Nigerian Postgraduate Medical Journal, 22(4), 195. https://doi.org/10.4103/1117-1936.173959

Bukhatwa, S.A., \& Elfakhri, M.M. (n.d.) The first PharmD program in Libya. Libyan International Medical University Journal [Epub ahead of print]. Available at: http://journal.limu.edu.ly/ preprintarticle. asp?id=261951

Faculty of Pharmacy - the University of Tripoli. (n.d.). Available from: https://pharm.uot.edu.ly/

Faculty of Pharmacy - University of Benghazi. (n.d.). Available from: http://pharm.uob.edu.ly

FIP (Federation I International Pharmaceutique) (2013). 2013 FIP Ed Global Education Report, 1-54

Global Knowledge Exchange Network. (2009). An Overview of Education and Training Requirements for Global Healthcare Professionals, (September). Available at: http://www.gken.org/ Docs/Workforce/Nursing Educ Reqs_FINAL 102609.pdf

Kheir, N., Zaidan, M., Younes, H., El Hajj, M., Wilbur, K., \& Jewesson, P.J. (2008). Pharmacy education and practice in 13 middle eastern countries. American Journal of Pharmaceutical Education, 72(6). https://doi.org/10.5688/aj7206133

Rouse, M., Mestrovic, A., \& Bruno, A. (2014). Quality Assurance of Pharmacy Education: the FIP Global Framework (online). Available at: https://www.fip.org/files/fip/PharmacyEducation/ Quality_Assurance/QA_Framework_2nd_Edition_online_version.pdf 